\title{
Photosynthetic characteristics of a tropical population of Nitella cernua (Characeae, Chlorophyta)
}

\author{
Jair Vieira Jr. and Orlando Necchi Jr."
}

Universidade Estadual Paulista, Departamento de Zoologia e Botânica, Rua Cristóvão Colombo, 2265, 15054-000 São José do Rio Preto, SP, Brasil.*Corresponding author: orlando@ibilce.unesp.br

Received: 12 June 2006; Returned for revision: 06 July 2006; Accepted: 25 September 2006

Photosynthetic characteristics (assessed by chlorophyll fluorescence and $\mathrm{O}_{2}$ evolution) were analysed monthly during one year in a tropical population of Nitella cernua from southeastern Brazil (20 $\left.50^{\prime} 32^{\prime \prime} \mathrm{S}, 49^{\circ} 26^{\prime} 15^{\prime \prime} \mathrm{W}\right)$. Parameters derived from photosynthesis-irradiance (PI) curves by fluorescence (high values of the photosynthetic parameter, $\mathrm{I}_{\mathrm{k}}$, and lack or low values of photoinhibition, $\beta$ ) suggested adaptation to high irradiance, whereas those by $\mathrm{O}_{2}$ evolution showed a different pattern (low values of $I_{k}$ and compensation irradiance, $I_{c}$, high values of photosynthetic efficiency, $\alpha$, and photoinhibition). Parameters from PI curves by $\mathrm{O}_{2}$ evolution suggested light acclimation: $\mathrm{I}_{\mathrm{k}}$ and maximum photosynthetic rate, $P_{\max }$ (as rETR, relative electron transfer rate) increased, whereas $\alpha$ became significantly lower under higher irradiance (winter). This pattern is an adjustment of both number and size of photosynthetic units. Photosynthetic performance assessed by fluorescence revealed two seasonal periods: higher values of $P_{\max }(\mathrm{rETR}), \mathrm{I}_{\mathrm{k}}$ and nonphotochemical quenching from October to March (rainy season), and lower values from April to October (dry season). Temperature responses were observed only in summer, but temperature optima were different between methods: peaks of net photosynthesis occurred at $20^{\circ} \mathrm{C}$, whereas rETR increased towards higher temperatures (up to $30^{\circ} \mathrm{C}$ ). Dark respiration increased with higher temperatures. Current velocity had a stimulatory effect on photosynthetic rates, as suggested by positive correlations with $P_{\max }(\mathrm{rETR})$ and $\alpha$. $\mathrm{pH}$ experiments revealed highest net photosynthetic rates under $\mathrm{pH} 4.0$, suggesting higher affinity for $\mathrm{CO}_{2}$ than $\mathrm{HCO}_{3}^{-}$. This broad range of responses of photosynthetic characteristics of this $N$. cernua population to irradiance, temperature, and $\mathrm{pH} /$ inorganic carbon reflects a wide tolerance to variations in these environmental variables, which probably contribute to the wide distribution of this species.

Key words: charophytes, irradiance, Nitella, $\mathrm{pH}$, photosynthesis, seasonal dynamics, temperature

Características fotossintéticas de uma população tropical de Nitella cernua (Characeae, Chlorophyta): Foram analisadas mensalmente, durante um ano, as características fotossintéticas (por meio de fluorescência da clorofila e evolução de $\mathrm{O}_{2}$ ) de

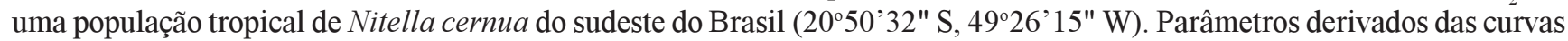
fotossíntese-irradiância (FI) por fluorescência (alto valor do parâmetro de saturação de luz, $\mathrm{I}_{\mathrm{k}}$, e ausência ou baixa fotoinibição, $\beta$ ) sugeriram adaptação a alta irradiância, enquanto aqueles por evolução de oxigênio mostraram adaptações à sombra (baixo valores de $I_{k}$ e de irradiância de compensação, $I_{c}$, altos valores de eficiência fotossintética, $\alpha$, e $\beta$ ). Parâmetros das curvas FI por oxigênio sugeriram aclimatação à luz: $\mathrm{I}_{\mathrm{k}}$ e taxa fotossintética máxima, $F_{\text {max }}$ (analisada como $\mathrm{rETR}$, taxa relativa de transporte de elétrons) aumentaram e $\alpha$ foi significativamente menor sob irradiância mais alta (inverno). Este padrão é um ajuste pelo número e tamanho das unidades fotossintéticas. O desempenho fotossintético avaliado por fluorescência revelou dois períodos sazonais: maiores valores de $F_{\max }, \mathrm{I}_{\mathrm{k}}$ e extinção não-fotoquímica, de outubro a março, e menores, de abril a outubro. Respostas de temperatura foram observadas apenas no verão, mas ótimos de temperatura foram diferentes: picos de fotossíntese líquida ocorreram a $20^{\circ} \mathrm{C}$, enquanto $\mathrm{rETR}$ aumentou com temperaturas mais altas (até $30^{\circ} \mathrm{C}$ ). A respiração no escuro aumentou com a elevação da temperatura. Velocidade da correnteza teve presumivelmente papel estimulatório sobre as taxas fotossintéticas, como sugerido pelas correlações positivas $\operatorname{com} F_{\max } \mathrm{e} \alpha$. Experimentos de $\mathrm{pH}$ revelaram taxas fotossintéticas mais altas em $\mathrm{pH} 4,0$, sugerindo maior afinidade por $\mathrm{CO}_{2}$. Essas amplas respostas das características fotossintéticas da população de $N$. cernua à irradiância, à temperatura e ao $\mathrm{pH} /$ carbono inorgânico refletem grande tolerância a variações dessas variáveis ambientes, que, provavelmente, contribuem para a extensa distribuição de $N$. cernua. Palavras-chave: carofitas, dinâmica sazonal, fotossíntese, irradiância, Nitella, $\mathrm{pH}$, temperatura

Abbreviations: chl - chlorophyll; $I_{c}$ - compensation irradiance; $I_{k}$ - light saturation parameter; NPQ - non-photochemical quenching coefficient; PI - photosynthesis-irradiance; $P_{\max }$ - maximum photosynthetic rate; rETR - relative electron transport rate; $\alpha$ - photosynthetic efficiency; $\beta$ - photoinhibition parameter 


\section{INTRODUCTION}

Ecophysiological investigations on photosynthetic characteristics of charophytes mostly focus on populations from temperate regions (Libbert and Walter, 1985; Howard-Williams and Schwarz, 1995; Schwarz et al., 1996; Küster et al., 2000). In contrast, similar approaches involving charophyte populations from tropical regions are relatively scarce (Vieira and Necchi, 2003). Investigations dealing with photosynthesis-irradiance (PI) curves have received great attention (Schwarz et al., 1996; Steinman et al., 1997; Menendez and Sanchez, 1998; Küster et al., 2000), involving light adaptability based on variations of photosynthetic parameters (light saturation parameter, $\mathrm{I}_{\mathrm{k}}$, compensation irradiance, $\mathrm{I}_{\mathrm{c}}$, maximum photosynthetic rate, $P_{\max }$, and photosynthetic efficiency, $\alpha)$.

Parameters derived from the PI curves (relatively low $I_{c}$ and $I_{k}$, and occurrence of photoinhibition) suggested adaptation to low irradiance for some charophyte species (Andrews et al., 1984; Menendez and Sanchez, 1998; Vieira and Necchi, 2003), whereas some investigations (Steinman et al., 1997; Küster et al., 2000) clearly indicated preferences for high irradiances in other species. Photoinhibition has been rarely reported in Characeae (Menendez and Sanchez, 1998; Vieira and Necchi, 2003). However, irradiances applied in some PI curves (e.g., 60-110 $\mu \mathrm{mol}$ $\mathrm{m}^{-2} \mathrm{~s}^{-1}$, Andrews et al., 1984; Schwarz et al., 1996) were not high enough to detect photoinhibition. On the other hand, some charophyte species do not grow under shade conditions (Moore, 1986) and photoinhibition has not been observed under irradiances as high as $1,600 \mu \mathrm{mol} \mathrm{m}^{-2} \mathrm{~s}^{-1}$ in species adapted to high-light conditions (Küster et al., 2000). Photoacclimation has been observed in some charophytes (Küster et al., 2000; Vieira and Necchi, 2003) with species-specific acclimation to low and high irradiances. The pattern to explain photoacclimation mechanisms seems to be a combination of changes in size and number of the photosynthetic units, i.e. a reaction center and its associated light-harvesting pigment complex.

Effects of temperature on photosynthesis and respiration rates in charophytes have been shown to be somewhat variable. Libbert and Walter (1985) reported no influence of temperature on net photosynthesis but observed a positive correlation with dark respiration, whereas Menendez and Sanchez (1998) found an apparent preference for lower temperatures (highest $P_{\max }$ at $10^{\circ} \mathrm{C}$ ). A trend for increasing dark respiration rates with higher temperatures has been observed in some studies (Libbert and Walter, 1985; Vieira and Necchi, 2003), which implies a decreased net primary production at higher temperatures. Data on best photosynthetic performances for charophyte species have been observed at a wide temperature range, suggesting that temperature optima can be species-specific.

Charophytes can grow in waters with high $\mathrm{pH}$ and most species tolerate a pH range between 6 and 9, although some species of Nitella have been reported from waters as low as pH 5 (Moore, 1986). Several species use bicarbonate, abundant in hard waters, as carbon source for photosynthesis (King and Nash, 1994; Van den Berg et al., 1998). Results from $\mathrm{pH}$ experiments showed highest photosynthetic rates at $\mathrm{pH} 4.0$, suggesting higher affinity for inorganic carbon in the form of carbon dioxide for most species tested (Vieira and Necchi, 2003). However, pH responses and the preference for a particular form of inorganic carbon in photosynthesis are still poorly investigated in charophytes.

Despite the investigations cited above, information is still scarce on responses of photosynthesis to environmental variables and is restricted to few species of charophytes. In addition, species or populations from tropical regions have been poorly investigated. This study involves a seasonal analysis of the photosynthetic performance in response to environmental variables (with emphasis on temperature, irradiance and $\mathrm{pH}$ ) of a tropical population of Nitella cernua A. Braun under field and laboratory conditions using the techniques of chlorophyll (chl) fluorescence and oxygen $\left(\mathrm{O}_{2}\right)$ evolution. It is part of a wider study, which also included phenology and coexistence with another macrophyte (Egeria najas Planchon) in a shallow habitat. The hypotheses tested in this study were: 1) this population of $N$. cernua is expected to have a well-defined seasonal pattern in photosynthetic characteristics, as a response to predictable changes in environmental variables (temperature and irradiance); 2) the alga will exhibit some characteristics of shade-adapted plants, based on previous results for other charophyte species (Andrews et al., 1984; Vieira and Necchi, 2003), as well as preference for free $\mathrm{CO}_{2}$ as inorganic carbon form for photosynthesis (Raven, 1997; Vieira and Necchi, 2003). 


\section{MATERIAL AND METHODS}

Field study: The field work was carried out monthly during one year (October 2001 to October 2002) in a third-order stream segment, which was a transition between an artificial pond and its outlet channel. The site is located within the "Noroeste Paulista" Ecological Station in northwestern São Paulo State, southeastern Brazil (2050’32" S, 49²6’15" W). The population of $N$. cernua occurs all the year round and the algal bed is mixed with a macrophyte (E. najas) covering an area of $12 \mathrm{~m}$ in length and 3.0 to $5.5 \mathrm{~m}$ in width and at a depth from 20 to $70 \mathrm{~cm}$.

Field measurements of photosynthesis were performed by in vivo chl fluorescence using a Diving-PAM underwater fluorometer (Walz, Effeltrich, Germany). Measurements were taken directly in the water for five replicates from different plants at the same place late in the morning (1030 to $1130 \mathrm{~h}$ in winter). Apices of algal thalli were placed directly on the tip of the fluorometer fiberoptic using the supplied magnet sample holder. Rapid light curves (White and Critchley, 1999) were generated and consisted of the fluorescence responses to eight increasing actinic irradiance steps within the range of 0 to $690 \mu \mathrm{mol}$ photons $\mathrm{m}^{-2} \mathrm{~s}^{-1}$, using the "light curve" option of the Diving-PAM. The exposure time at each irradiance was $15 \mathrm{~s}$, each separated by a $0.8 \mathrm{~s}$ saturating flash $(\sim 6,000$ $\mu \mathrm{mol}$ photons $\mathrm{m}^{-2} \mathrm{~s}^{-1}$ ). The illumination periods of rapid light curves are too short to achieve true steady-states but provide sound information on the overall photosynthetic performance of a plant (White and Critchley, 1999). The Diving-PAM records all relevant fluorescence parameters, as well as actinic irradiance, and data were processed using the supplied WinControl software. Three parameters were determined from each sample at each irradiance level: 1) effective quantum yield of PSII, $\Delta \mathrm{F} / \mathrm{F}_{\mathrm{m}}{ }^{\prime}$, in which $\Delta \mathrm{F}=\mathrm{F}_{\mathrm{m}}{ }^{\prime}-\mathrm{F}_{\mathrm{t}}\left(\mathrm{F}_{\mathrm{m}}{ }^{\prime}\right.$ is the maximal fluorescence of an illuminated sample, and $F_{t}$ is the transient fluorescence); 2) relative electron transport rate, $\mathrm{rETR}=\Delta \mathrm{F} / \mathrm{F}_{\mathrm{m}}{ }^{\prime} \times$ actinic irradiance $\times 0.5 \times 0.95$ [the first multiplication factor $(0.5)$ was introduced since the transport of a single electron requires the absorption of two quanta, and the second factor $(0.95)$ represents an estimation of irradiance absorption based on measurements made with and without the alga within a circle of $0.5 \mathrm{~cm}$ in diameter - similar to the area of the fluorometer fiberoptic tip]; and 3) non-photochemical quenching coefficient (NPQ), as a measure of heat dissipation of absorbed light energy, was calculated as $\mathrm{NPQ}=\left(\mathrm{F}_{\mathrm{m}}-\mathrm{F}_{\mathrm{m}}{ }^{\prime}\right) / \mathrm{F}_{\mathrm{m}}{ }^{\prime}$, in which $\mathrm{F}_{\mathrm{m}}$ is the maximal fluorescence of a dark-adapted sample. Such a coefficient was estimated from the highest irradiance $\left(690 \mu \mathrm{mol} \mathrm{m} \mathrm{m}^{-2} \mathrm{~s}^{-1}\right)$ applied when obtaining the light response curves. The calculations followed Schreiber et al. (1994) and Kromkamp et al. (1998), and the terminology for chl fluorescence described by van Kooten and Snel (1990) was adopted. Curves of PI were generated on the basis of rETR and the respective parameters were calculated by the equation of Platt et al. (1980): $\alpha E T R$, $P_{\text {max }}\left(\mathrm{rETR}_{\max }\right), \mathrm{I}_{\mathrm{k}}, \mathrm{I}_{\mathrm{c}}$ and photoinhibition parameter $(\beta E T R)$. The values of $\alpha E T R$ were determined by linear fitting using the first three points of the rETR versus irradiance curve (Conde-Álvarez et al., 2002).

Environmental variables were measured simultaneously with the photosynthetic performance. Temperature and $\mathrm{pH}$ were measured immediately below the surface with a Horiba U-10 water quality checker (Horiba, Kyoto, Japan). Current velocity and irradiance were measured close to the algal thalli (Vieira and Necchi, 2002, 2003) using, respectively, a Swoffer current velocity meter (Swoffer Instruments, Seattle, USA) and a quantum meter (Li-189, Li-Cor, Lincoln, USA) coupled to a Li-193 SA spherical quantum sensor.

Laboratory study: Measurements by $\mathrm{O}_{2}$ evolution were made in the laboratory and followed the general procedures described in previous studies (Vieira and Necchi, 2003; Necchi 2004a,b). Photosynthesis and dark respiration rates were determined by changes in $\mathrm{O}_{2}$ concentration using the light and dark bottle technique (Littler and Arnold, 1985; Thomas, 1988). Initial and final $\mathrm{O}_{2}$ concentrations of incubated samples were measured with a YSI model 5000 $\mathrm{O}_{2}$ meter (Yellow Springs Instruments, Yellow Springs, USA), equipped with a self-stirring probe, and calculations were made according to Littler and Arnold (1985). Incubations were made with orbital agitation $(100 \pm 5 \mathrm{rpm})$ and digital temperature control. Frontal illumination was supplied by one to three cool-white fluorescent lamps (Osram $15 \mathrm{~W}$ ). Plants were incubated in $100 \mathrm{~mL}$ borosilicate glass bottles (98.5\% transparency). Dark bottles were covered with thick black plastic. In order to prevent inorganic carbon depletion during incubations, stream water samples were supplied three times with $2 \mathrm{mM}$ $\mathrm{NaHCO}_{3}$ (1mL solution for each $100 \mathrm{~mL}$ of water sampled). 
Curves of PI were made under constant temperature: $20 \pm 0.5^{\circ} \mathrm{C}$ in winter (June to September) and $25 \pm 0.5^{\circ} \mathrm{C}$ in summer (December to March) using eight increasing actinic irradiance levels within the range of 0 to $425 \mu \mathrm{mol}$ photons $\mathrm{m}^{-2} \mathrm{~s}^{-1}$. These encompass the saturation ranges previously reported for freshwater macroalgae (Leukart and Hanelt, 1995; Hill, 1996) and charophytes (Vieira and Necchi, 2003). Incubation lengths were of $30 \mathrm{~min}$ for each irradiance level. Parameters from the PI curves were calculated by the equation proposed by Platt et al. (1980) that includes a photoinhibition parameter because some charophyte species exhibited photoinhibition in previous studies (Vieira and Necchi, 2003; Necchi, 2004b).

Responses of photosynthetic performance to temperature were tested in the laboratory by the two techniques during the most contrasting seasons: August (winter) and February (summer). Five temperatures were tested $\left(10,15,20,25\right.$ and $\left.30^{\circ} \mathrm{C}\right)$ encompassing the ranges reported for charophytes in tropical and sub-tropical regions (Vieira and Necchi, 2002, 2003; Vieira et al., 2003). The same set of specimens (fresh weights of $75 \pm 15 \mathrm{mg}$ in each replicate) was used first for measurements by $\mathrm{O}_{2}$ evolution and then by the fluorescence technique. Incubations were made for $45 \mathrm{~min}$ at each temperature in increasing order under constant irradiance $\left(170 \mu \mathrm{mol} \mathrm{m}^{-2}\right.$ $\left.\mathrm{s}^{-1}\right)$. This irradiance was chosen because it is an intermediary value in relation to the saturation parameter $\left(\mathrm{I}_{\mathrm{k}}\right)$ found in PI curves for charophytes in a previous study (Vieira and Necchi, 2003) and preliminary tests.

$\mathrm{pH}$ experiments were conducted under constant temperature $\left(20^{\circ} \mathrm{C}\right)$ and irradiance $\left(170 \mu \mathrm{mol} \mathrm{m}^{-2} \mathrm{~s}^{-1}\right)$ with incubation lengths of $45 \mathrm{~min}$. The $\mathrm{pH}$ values tested were based on the typical relationship of $\mathrm{pH}$ and inorganic carbon form in freshwater (Wetzel and Likens, 2000): $\mathrm{pH}$ 4.0 ca. $100 \%$ of $\mathrm{CO}_{2} / \mathrm{H}_{2} \mathrm{CO}_{3} ; \mathrm{pH} 6.5$ ca. $50 \%$ of both $\mathrm{CO}_{2}$ and $\mathrm{HCO}_{3}^{-} ; \mathrm{pH} 8.5 \mathrm{ca} .100 \%$ of $\mathrm{HCO}_{3}^{-}$. $\mathrm{pH}$ was adjusted by addition of $0.5 \mathrm{~N} \mathrm{HCl}$ or $\mathrm{KOH}$ to the stream water samples.

Data were analyzed by Student's $t$ test or one-way analysis of variance (ANOVA; Zar, 1999) and NewmanKeuls multiple comparison test to detect significant differences in photosynthetic parameters, months or environmental variables as factors. Relationships among photosynthetic parameters and environmental variables were evaluated by the Pearson moment-product correlation coefficient (Zar, 1999). Statistical tests were performed by Statsoft Statistica 6.0 software, whereas graphs were made by Microcal Origin 5.0.

\section{RESULTS}

Environmental variables: Only the environmental variables most closely related to the photosynthetic parameters are presented (Figure 1): temperature, $\mathrm{pH}$, irradiance and current velocity. All these variables varied significantly along the year $(P<0.05)$ with the following annual averages (Figure 1): temperature $\left(25.5 \pm 0.8^{\circ} \mathrm{C}\right), \mathrm{pH}$ $(8.1 \pm 0.2)$, irradiance $\left(995 \pm 110 \mu \mathrm{mol} \mathrm{m}^{-2} \mathrm{~s}^{-1}\right)$ and current velocity $\left(6.0 \pm 4.8 \mathrm{~cm} \mathrm{~s}^{-1}\right)$. Temperature values were higher (above annual average) from October through April, whereas $\mathrm{pH}$ was lower from February through June compared to the other months (Figure 1). Irradiance was high $\left(>1,000 \mu \mathrm{mol} \mathrm{m} \mathrm{m}^{-2} \mathrm{~s}^{-1}\right)$ throughout the year, except on some cloudy days (November, February, April and May), whereas current velocity was slow $\left(\leq 5 \mathrm{~cm} \mathrm{~s}^{-1}\right)$ throughout the year, except from January through March (Figure 1).

Curves of $P I$ : Monthly variation of photosynthetic parameters derived from PI curves for chl fluorescence (Figure 2) was characterized by lack or low values of photoinhibition $(\beta=0.05 \pm 0.11)$, moderate to high values of $P_{\max }(39.1 \pm 14.0 \mathrm{rETR})$ and $\alpha(0.20 \pm 0.03)$, and relatively high values of $\mathrm{I}_{\mathrm{k}}\left(195 \pm 50 \mu \mathrm{mol} \mathrm{m} \mathrm{m}^{-2} \mathrm{~s}^{-1}\right)$. Quantum yield was widely variable $(0.56 \pm 0.10)$ throughout the period, as well as NPQ (1.2 \pm 0.7$)$. Highly significant differences for all parameters were found by ANOVA $(P<0.001)$, as well as by the Newman-Keuls test (indicated by distinct letters on Figure 2), throughout the year.

From October to March $P_{\text {max }}$ (rETR) tended to increase (except for low values in February), but showed lower values from April to October, with the lowest values in August (Figure 2). Similar trends were also observed for $I_{k}$ and NPQ, which had a highly significant positive correlation $(r=0.89-0.91, P<0.001)$ with $P_{\max }$ (rETR). Values of quantum yield fluctuated along the year with no clear seasonal pattern, except for consistently low values from October to December and high values from January to March (Figure 2). A similar trend was observed for $\alpha$ with a highly significant positive correlation $(r=0.92, P<$ $0.001)$ with quantum yield. Photoinhibition was observed only in February, May and June (Figure 2). Among the environmental variables, we only found positive correlations of $P_{\max }$ (rETR), $\mathrm{I}_{\mathrm{k}}, \alpha$ and NPQ with current velocity $(r=0.60-0.80, P<0.05)$ and no significant correlation with temperature or irradiance. 



Figure 1. Values of temperature, $\mathrm{pH}$, irradiance and current velocity for the population of Nitella cernua from October 2001 to October 2002. Each point is the mean of three (for temperature and $\mathrm{pH}$ ) or five (for irradiance and current velocity) replicates. Bars represent SD.

Photosynthetic parameters derived from PI curves for $\mathrm{O}_{2}$ evolution (Table 1) were all significantly different between winter and summer, except dark respiration. Higher values of $P_{\max }(\mathrm{rETR}), \mathrm{I}_{\mathrm{k}}$ and net photosynthesis/ dark respiration ratio were observed in winter, whereas $I_{c}$, $\alpha$ and $\beta$ were higher in summer.

Responses to temperature: Rates of photosynthesis responded differently to the variations in the experimentally manipulated range of temperature (Figures 3 and 4). Fluorescence data showed that temperature had a significant effect $(P<0.05)$ on photosynthetic rates
(rETR) only in summer (Figure 4). In summer rETR was positively correlated with temperature $(r=0.96, P<0.01)$. Temperature had an opposite effect on NPQ in comparison to $\mathrm{rETR}$, with significant variation $(P<0.05)$ only in winter (Figure 4), with significantly higher values at 15 and $20^{\circ} \mathrm{C}$. No significant correlation between rETR and NPQ in any of the seasons was found.

Temperature had a significant effect on net photosynthesis only in summer $(P<0.01)$, with the highest values at $20^{\circ} \mathrm{C}$ and the lowest at $30^{\circ} \mathrm{C}$ (Figure 3). Rates of dark respiration were significantly different $(P<0.001)$ in summer and winter and positively correlated to temperature 
Table 1. Parameters of the photosynthesis-irradiance curves $\left(P_{\max }\right.$, maximum photosynthetic rate; $\alpha$, photosynthetic efficiency; $\beta$, photoinhibition parameter; $\mathrm{I}_{\mathrm{k}}$, light saturation parameter; $\mathrm{I}_{\mathrm{c}}$ compensation irradiance; and $\mathrm{P} / \mathrm{R}, P_{\max }$ to dark respiration ratio) for the population of Nitella cernua measured by $\mathrm{O}_{2}$ evolution in two periods of the year. Data are expressed as means $\pm \mathrm{SD}(n=5)$. Distinct letters indicate significant differences $(P<0.05)$ by Student's $t$ test

\begin{tabular}{lcc}
\hline \multicolumn{1}{c}{ Photosynthetyc parameters } & \multicolumn{2}{c}{ Sampling periods } \\
\cline { 2 - 3 }$P_{\max }\left(\mathrm{mg} \mathrm{O}_{2} \mathrm{~g}^{-1} \mathrm{DW} \mathrm{h}^{-1}\right)$ & $0.9 \pm 0.4 \mathrm{a}$ & January \\
$\alpha\left(\mathrm{mg} \mathrm{O}_{2} \mathrm{~g}^{-1} \mathrm{DW} \mathrm{h}^{-1}\left(\mu \mathrm{mol} \mathrm{m}^{-2} \mathrm{~s}^{-1}\right)^{-1}\right)$ & $0.37 \pm 0.1 \mathrm{a}$ & $2.3 \pm 0.5 \mathrm{~b}$ \\
$\beta\left(\mathrm{mg} \mathrm{O}_{2} \mathrm{~g}^{-1} \mathrm{DW} \mathrm{h}^{-1}\left(\mu \mathrm{mol}^{-2} \mathrm{~s}^{-1}\right)^{-1}\right)$ & $-0.67 \pm 0.0 \mathrm{a}$ & $0.21 \pm 0.0 \mathrm{~b}$ \\
$\mathrm{I}_{\mathrm{k}}\left(\mu \mathrm{mol} \mathrm{m}^{-2} \mathrm{~s}^{-1}\right)$ & $3.2 \pm 1.2 \mathrm{a}$ & $-0.08 \pm 0.03 \mathrm{~b}$ \\
$\mathrm{I}_{\mathrm{c}}\left(\mu \mathrm{mol} \mathrm{m}^{-2} \mathrm{~s}^{-1}\right)$ & $2.7 \pm 0.3 \mathrm{a}$ & $15.5 \pm 6.1 \mathrm{~b}$ \\
Dark respiration $\left(\mathrm{mg} \mathrm{O}_{2} \mathrm{~g}^{-1} \mathrm{DW} \mathrm{h}^{-1}\right)$ & $1.3 \pm 0.2 \mathrm{a}$ & $2.1 \pm 0.7 \mathrm{~b}$ \\
$\mathrm{P} / \mathrm{R}$ & $0.7 \pm 0.2 \mathrm{a}$ & $1.1 \pm 0.1 \mathrm{a}$ \\
Irradiance $\left(\mu \mathrm{mol} \mathrm{m}^{-2} \mathrm{~s}^{-1}\right)$ & $650 \pm 55 \mathrm{a}$ & $2.1 \pm 0.4 \mathrm{~b}$ \\
\hline
\end{tabular}
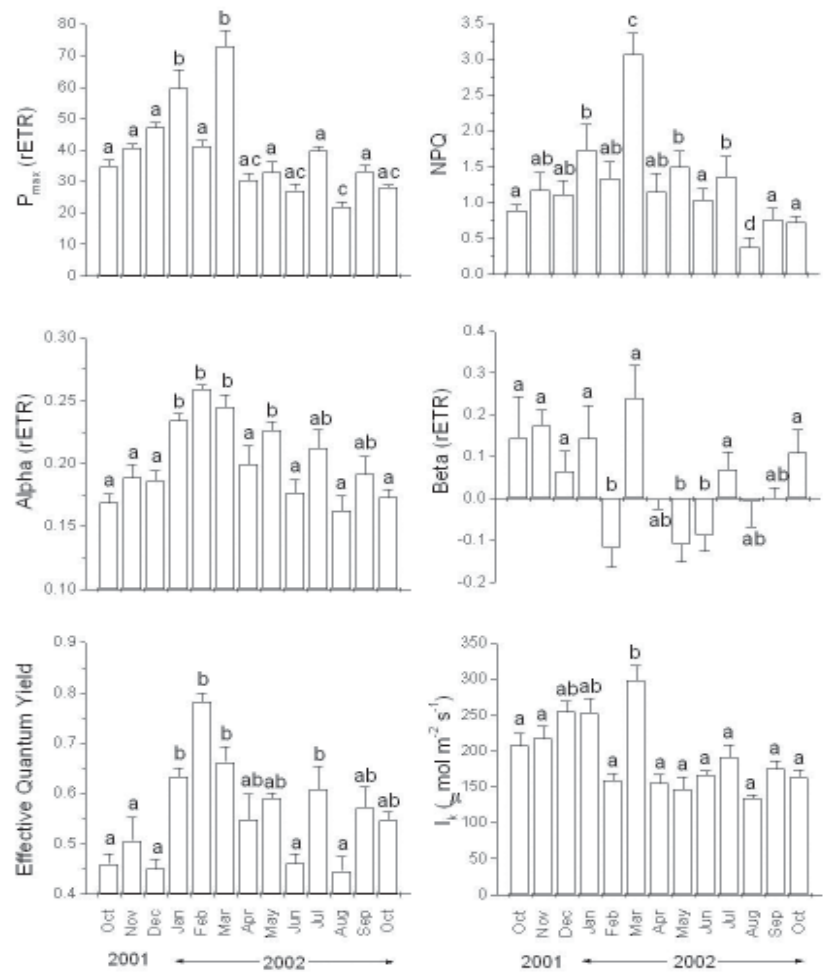

Figure 2. Parameters of the photosynthesis-irradiance curves $\left(P_{\max }\right.$, maximum photosynthetic rate; $\mathrm{rETR}$, relative electron transport rate; $\alpha$, photosynthetic efficiency; effective quantum yield; NPQ, non-photochemical quenching coefficient; $\beta$, photoinhibition parameter; and $\mathrm{I}_{\mathrm{k}}$, light saturation parameter) for the population of Nitella cernua measured by chlorophyll fluorescence from October 2001 to October 2002. Each column represents the mean of five replicates, and bars indicate SD. Means followed by different letters are significantly different from each other $(P<0.05$; Newman-Keuls test).

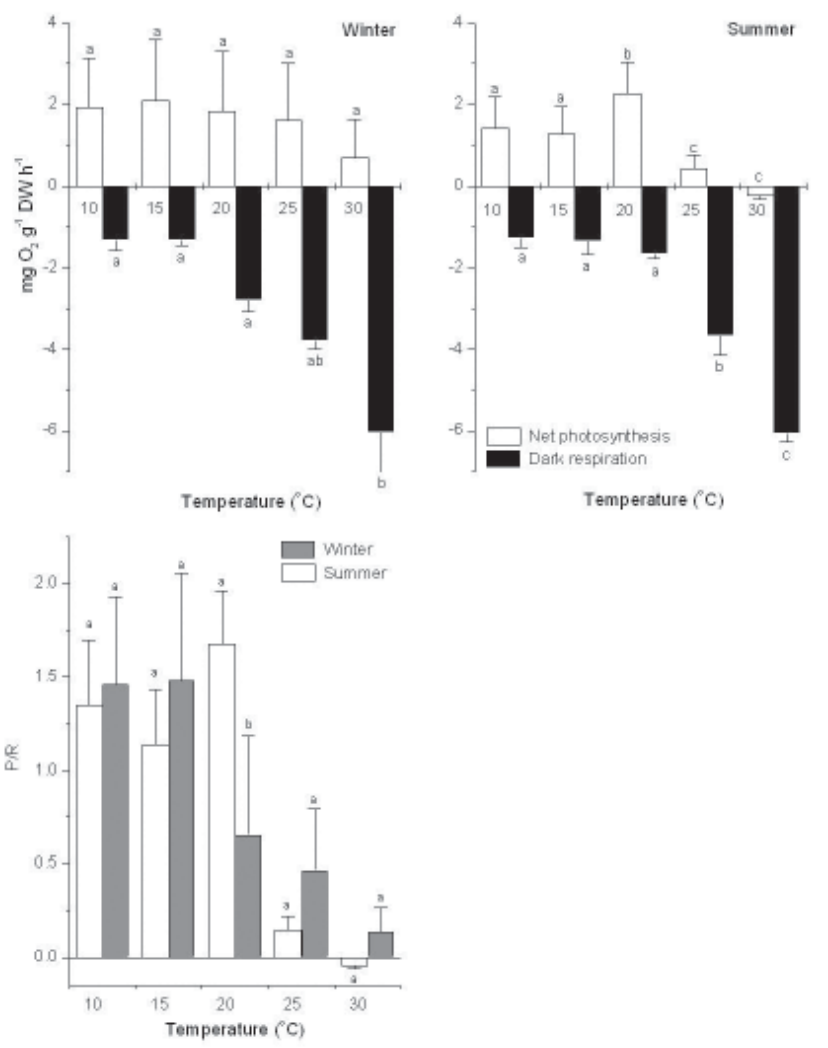

Figure 3. Rates of net photosynthesis and dark respiration under five temperatures for the population of Nitella cernua measured by $\mathrm{O}_{2}$ evolution in two periods of the year at $170 \mu \mathrm{mol}$ photons $\mathrm{m}^{-2} \mathrm{~s}^{-1}$. P/R represents the ratio of $P_{\max }$ to dark respiration. Statistics as in Figure 2. 


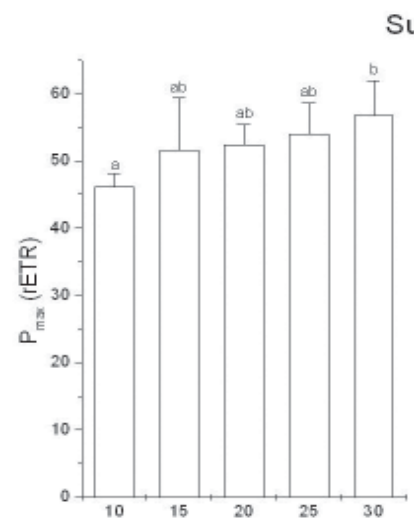

Summer

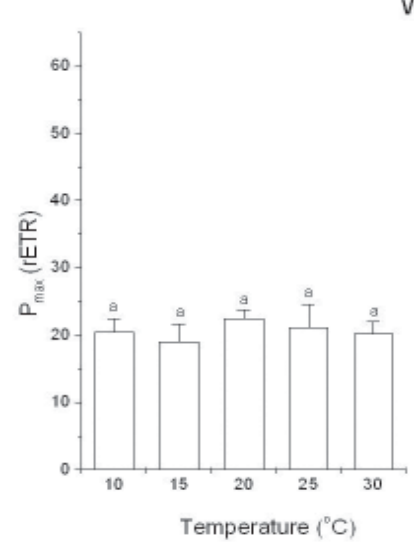

Winter

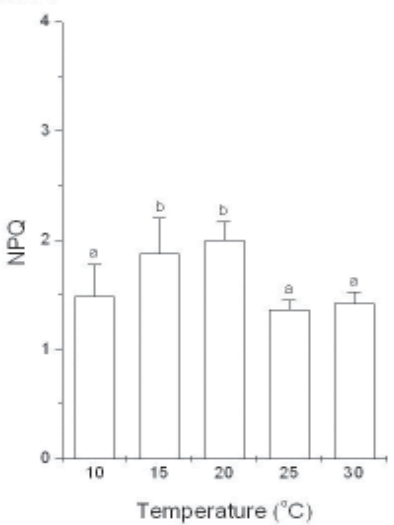

Figure 4. Photosynthetic parameters $\left(P_{\max }\right.$, maximum photosynthetic rate, and NPQ, non-photochemical quenching coefficient) for the population of Nitella cernua measured by chlorophyll fluorescence under five temperatures in two periods of the year. Statistics as in Figure 2 .

$(r=0.91$ to 0.96$)$. The ratio of net photosynthesis/dark respiration had a decreasing trend towards higher temperatures for both seasons, with peaks at $20^{\circ} \mathrm{C}$ in summer and at $15^{\circ} \mathrm{C}$ in winter (Figure 3). That ratio was negatively correlated to temperature $(r=-0.96, P<0.01)$ in winter. The alga kept best performances (higher values both of net photosynthetic rates and net photosynthesis/ dark respiration ratio) at temperatures considerably lower $\left(10-20^{\circ} \mathrm{C}\right)$ than the mean annual temperature $\left(25.6 \pm 2.8^{\circ} \mathrm{C}\right)$. In addition, optimum experimental temperatures (Figure 3 ) were far below the ambient temperatures in both seasons: winter $\left(15\right.$ and $22.2^{\circ} \mathrm{C}$; optimum and ambient temperatures, respectively) and summer (20 and $\left.27.1^{\circ} \mathrm{C}\right)$.

Responses to $p H$ : Net photosynthetic rates were significantly higher $(P<0.01)$ at $\mathrm{pH} 4.0$ than at the other
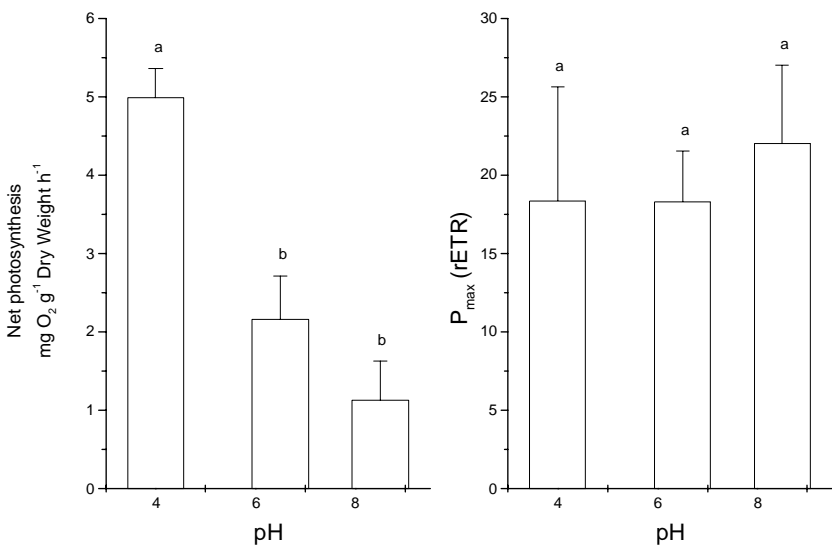

Figure 5. Photosynthetic rates for the population of Nitella cernua measured by $\mathrm{O}_{2}$ evolution (left) and chlorophyll fluorescence (right) under three values of $\mathrm{pH}$ at $20^{\circ} \mathrm{C}$ and $170 \mathrm{mmol}$ photons $\mathrm{m}^{-2} \mathrm{~s}^{-1}$. Statistics as in Figure 2.

Table 2. Initial and final $\mathrm{pH}$ values measured during the incubations of the population of Nitella cernua for photosynthetic rate determinations by $\mathrm{O}_{2}$ evolution. Data are expressed as means $\pm \mathrm{SD}(n=3)$. Distinct letters indicate significant differences $(P<0.05)$ by Student's $t$ test

\begin{tabular}{ccc}
\hline \multirow{2}{*}{$\mathrm{pH}$ treatments } & \multicolumn{2}{c}{$\mathrm{pH}$ values } \\
\cline { 2 - 3 } & Initial & Final \\
\hline $\mathrm{pH} 4.0$ & $4.00 \pm 0.05 \mathrm{a}$ & $4.96 \pm 0.11 \mathrm{~b}$ \\
$\mathrm{pH} 6.5$ & $6.50 \pm 0.05 \mathrm{a}$ & $6.99 \pm 0.03 \mathrm{~b}$ \\
$\mathrm{pH} 8.5$ & $8.50 \pm 0.05 \mathrm{a}$ & $7.57 \pm 0.04 \mathrm{~b}$ \\
\hline
\end{tabular}

two values tested, with an evident decreasing trend towards higher $\mathrm{pH}$ values (Figure 5). Photosynthetic rates also changed $\mathrm{pH}$ values of the water, as observed by comparison before and after the incubations (Table 2). Significantly different values between initial and final $\mathrm{pH}$ values were observed for the three $\mathrm{pH}$ values tested. Greater differences were generally coincident with the $\mathrm{pH}$ level with higher photosynthetic rates, except at $\mathrm{pH}$ 8.5. In contrast, $\mathrm{pH}$ had no significant effect on photosynthetic rates (rETR) measured by chl fluorescence (Figure 5).

\section{DISCUSSION}

Some parameters derived from the PI curves by chl fluorescence (relatively high $I_{k}$ and lack or low levels of photoinhibition) suggested adaptation to high irradiance 
for this species, which is consistent with its occurrence in shallow habitats. These results agree with previous studies in shallow waters (e.g. Steinman et al., 1997; Küster et al., $2000)$ but contrast studies of other habitats where charophytes revealed adaptations to low irradiances (Andrews et al., 1984; Menendez and Sanchez, 1998; Vieira and Necchi, 2003). On the other hand, results by $\mathrm{O}_{2}$ evolution showed a trend toward adaptations to shade conditions as indicated by the relatively low values of $I_{k}$ and $\mathrm{I}_{c}$, high values of $\alpha$ and occurrence of photoinhibition. This pattern was most evident in summer. Our values were near or below the lower limits of the ranges previously reported for $\mathrm{I}_{\mathrm{c}}\left(4-100 \mu \mathrm{mol} \mathrm{m} \mathrm{s}^{-2}\right)$ and $\mathrm{I}_{\mathrm{k}}\left(29-554 \mu \mathrm{mol} \mathrm{m} \mathrm{m}^{-2}\right.$ $\mathrm{s}^{-1}$ ) (Howard-Williams et al., 1995; Steinman et al., 1997; Menendez and Sanchez, 1998; Vieira and Necchi, 2003), reinforcing the adaptation to shade conditions. The ratio of net photosynthesis/dark respiration revealed relatively high net carbon gain in winter and low in summer, which was essentially due to variations in net photosynthetic rates, since respiration was relatively similar. This physiological parameter, associated with the fact that the alga is relatively abundant (Vieira and Necchi, unpublished), suggest that it may contribute importantly to primary production at least during part of the year.

Parameters derived from PI curves by $\mathrm{O}_{2}$ evolution in summer and winter suggested light acclimation: $\mathrm{I}_{\mathrm{k}}$ and $P_{\text {max }}$ (rETR) increased, whereas $\underset{\alpha}{\iota}$ became significantly lower under higher irradiance (winter). In this case, more light was required to saturate photosynthesis (indicated by higher $\mathrm{I}_{\mathrm{k}}$ ). This light acclimation pattern was similar to that seen for other charophytes: Lamprothamnium papulosum (Küster et al., 2000) and two populations of $N$. subglomerata (Vieira and Necchi, 2003).

The seasonal performance of photosynthetic parameters by chl fluorescence revealed two periods: the first from October to March characterized by higher photosynthetic activity as indicated by increasing values of $P_{\max }$ (rETR), $\mathrm{I}_{\mathrm{k}}$ and NPQ, and the second with lower values of these parameters extending from April to October. Interestingly, these periods corresponded to some key phenological characteristics (Vieira and Necchi, unpublished): the former with specimens lacking or with few reproductive structures and large vegetative structures, whereas the latter had the opposite trend. The photosynthetic trends may indicate resource allocation for reproduction, as has been reported for charophyte species (Casanova, 1994).
Effects of temperature on photosynthesis and respiration rates have been demonstrated in charophytes (Libbert and Walter, 1985; Menendez and Sanchez, 1998; Vieira and Necchi, 2003). Libbert and Walter (1985) reported no influence of temperature on net photosynthesis, whereas Menendez and Sanchez (1998) and Vieira and Necchi (2003) showed evident responses, with preferences to definite ranges of temperatures by some species. Menendez and Sanchez (1998) reported that $P_{\max }$ (rETR) was highest at $10^{\circ} \mathrm{C}$ in Chara hispida and Vieira and Necchi (2003) found highest rates for Chara species at $10-15^{\circ} \mathrm{C}$ and for Nitella at $20-25^{\circ} \mathrm{C}$, whereas the peak for $N$. furcata var. sieberi was observed at $15^{\circ} \mathrm{C}$ by Necchi (2004a). Highest ETR values were observed at $15^{\circ} \mathrm{C}$ for $N$. furcata var. sieberi by Necchi (2004a) but with no significant differences in the range of 10 to $30^{\circ} \mathrm{C}$. In addition, temperature optima can be species-specific and differences even between populations of a same species have been reported (Vieira and Necchi, 2003). Such observations illustrate that for relatively high light (shallow) charophyte populations, where irradiance is seldom limiting for photosynthesis, some other factors (e.g. reproductive allocation, temperature and carbon availability) are likely to have a strong influence on growth. Our initial hypothesis that $N$. cernua would present some characteristics of shade-adapted plants was partially confirmed. However, this alga is not clearly shade or high light adapted.

The different performances evidenced by each measurement technique in response to irradiance and temperature can be attributed to dependence on distinct factors. Increases in temperature have been shown to generally induce higher ETR values in some species, due to increased enzymatic activity, whereas $\mathrm{O}_{2}$ evolution generally increases at lower temperatures and decreases at when higher temperatures (Ensminger et al., 2001; Necchi, 2004a). Our results are consistent with this pattern, with higher performances of net photosynthesis during winter and increasing trend of ETR towards higher temperatures in summer. The increments of enzymatic activity are compensated by increased respiration and other mechanisms, e.g. increases in pseudocyclic electron transport (Mehler reaction) and enhanced photorespiration, leading to decreases in net photosynthesis (Davison, 1991; Ensminger et al., 2001). In addition, atypical values under extreme combinations 
of irradiance and temperature (e.g. high temperature and irradiance for $N$. cernua) are also responsible for the nonlinear relationships of $\mathrm{O}_{2}$ evolution and ETR in freshwater macroalgae (Ensminger et al., 2001; Necchi, 2004a).

The increasing trend of dark respiration with higher temperatures observed in this study is consistent with data reported for freshwater macroalgae (Libbert and Walter, 1985; Necchi and Zucchi, 2001; Necchi and Vieira, 2003; Necchi, 2004a) and higher plants (Atkin and Tjoelker, 2003). This trend suggests a decreasing balance between net primary production and temperature, representing more critical conditions towards higher temperatures for most species. Our results agree with this pattern. In addition, the species had best photosynthetic performances at temperatures considerably lower than the ambient temperature. Thus, tropical species face additional constraints to adapt their physiological characteristics to the high temperatures that typically prevail during most part of the year and day period in tropical regions (Necchi, 2004a).

Current velocity seemed to have a stimulatory effect on photosynthetic rates measured by chl fluorescence, as suggested by positive correlations with $P_{\text {max }}$ (rETR) and $\alpha$. Raven (1992) hypothesized that the simple tensile force exerted by moderate flowing water has a stimulatory effect on the growth of stream macroalgae under resourcesaturated conditions. Data from this study support this idea, although it has not yet been tested experimentally.

Results from $\mathrm{pH}$ experiments revealed highest photosynthetic rates under $\mathrm{pH} 4.0$, suggesting higher affinity for inorganic carbon in the form of carbon dioxide. However, the alga has also demonstrated capacity to use bicarbonate as well, considering photosynthetic performances and changes in water $\mathrm{pH}$ after incubations under $\mathrm{pH} 6.5$ and 8.5. These data are quite divergent of the species occurrence in the field under higher $\mathrm{pH}$ values $(\mathrm{pH} 8.1 \pm 0.6)$, with high predominance of bicarbonate (>90\%; Wetzel and Likens, 2000). According to Raven (1992), two main mechanisms for inorganic carbon acquisition occur in ecorticate charophytes (like Nitella), both involving extracellular chemical transformation (on the plant surface): 1) "acid zones" consisting of a catalytic agent $\left(\mathrm{H}^{+}\right)$acting to convert $\mathrm{HCO}_{3}{ }^{-}$(present in the water) into $\mathrm{CO}_{2}$ (taken up by the cells); and 2) enzymatic conversion by carbonic anhydrase. Ecorticate charophytes are prime algal examples of the first mechanism. Under experimental lower $\mathrm{pH}$, direct absorption of $\mathrm{CO}_{2}$ was presumably a more efficient and economic mode for carbon acquisition, since no need of extracellular conversion or concentrating mechanisms would be required. The findings are consistent with our initial hypothesis that $N$. cernua would be expected to present preference for $\mathrm{CO}_{2}$.

Photosynthetic characteristics of the $N$. cernua population exhibited a relatively broad range of responses to irradiance, temperature and $\mathrm{pH} /$ inorganic carbon, reflecting a wide tolerance to variations in these environmental variables. Thus, the initial hypothesis that this alga would have a relatively well-defined seasonal pattern in response to environmental variables (particularly temperature and irradiance) was confirmed. This probably contributes to its wide spatial distribution in several scales, from drainage basin to regions and biomes (Vieira et al., 2003), since it is one of the most widespread charophyte species in Brazil (Bicudo and Yamaoka, 1978).

Acknowledgements: This work was supported by research grants from FAPESP (01/06139-3) and CNPq (520551/96-6) awarded to $\mathrm{ONJ}$ and a $\mathrm{PhD}$ scholarship to JVJ. We are grateful to Álvaro Luiz Hattnher for reviewing the English text.

\section{REFERENCES}

Andrews M, Box R, McInroy S, Raven JA (1984) Growth of Chara hispida. II. Shade adaptation. J. Ecol. 72:885895.

Atkin OK, Tjoelker MG (2003) Thermal acclimation and the dynamic response of plant respiration to temperature. Trends Plant Sci. 8:343-351.

Bicudo RMT, Yamaoka DM (1978) O gênero Nitella (Charophyceae) no Brasil, 1: subgênero Nitella. Acta Biol. 7:77-98.

Casanova MT (1994) Vegetative and reproductive responses of charophytes to water-level fluctuations in permanent and temporary wetlands in Australia. Aust. J. Mar. Freshwater Res. 45:1409-1419.

Conde-Álvarez RM, Pérez-Rodríguez E, Altamirano M, Nieto JM, Abdala R, Figueroa FL, Flores-Moya A (2002) Photosynthetic performance and pigment content in the aquatic liverwort Riella helicophylla under natural solar irradiance and solar irradiance without ultraviolet light. Aquat. Bot. 73:47-61.

Davison IR (1991) Environmental effects on algal photosynthesis: temperature. J. Phycol. 27:2-8. 
Ensminger I, Xyländer M, Hagen C, Braune W (2001) Strategies providing success in a variable habitat: III. Dynamic control of photosynthesis in Cladophora glomerata. Plant Cell Environ. 24:769-779.

Hill WR (1996) Effects of light. In: Stevenson RJ, Bothwell ML and Lowe, RL (eds), Algal Ecology: Freshwater Benthic Ecosystems, pp. 121-148. Academic Press, San Diego.

Howard-Williams C, Schwarz AM (1995) Deep-water aquatic plant communities in an oligotrophic lake: physiological responses to variable light. Freshwater Biol. 33:91-102.

King JJ, Nash DW (1994) The Charophyta of County Dublin. Proc. Royal Irish Acad. B. 64:255-264.

Kromkamp J, Barranguet C, Peene J (1998) Determination of microphytobenthos PSII quantum efficiency and photosynthetic activity by means of variable chlorophyll fluorescence. Mar. Ecol.-Progr. Ser. 162:4555.

Küster A, Schaible R, Schubert H (2000) Light acclimation of the charophyte Lamprothamnium papulosum. Aquat. Bot. 68:205-216.

Leukart P, Hanelt D (1995) Light requirements for photosynthesis and growth in several macroalgae from a small soft-water stream in the Spessart Mountains, Germany. Phycologia 34:528-532.

Libbert E, Walter T (1985) Photosynthetic production of a brackish water community of Chara tomentosa L. and its dependence on environmental conditions. Int. Rev. Ges. Hydrobiol. 70:359-368.

Littler MM, Arnold KE (1985) Electrodes and chemicals. In: Littler MM, Littler DS (eds), Handbook of Phycological Methods; Ecological Field Methods: Macroalgae, pp. 349-375. Cambridge University Press, Cambridge.

Menendez M, Sanchez A (1998) Seasonal variations in PI responses of Chara hispida L. and Potamogeton pectinatus $\mathrm{L}$. from stream Mediterranean ponds. Aquat. Bot. 61:1-15.

Moore JA (1986) Charophytes of Great Britain and Ireland. Botanical Society of the British Isles, London.

Necchi O Jr (2004a) Photosynthetic responses to temperature in tropical lotic macroalgae. Phycol. Res. 52:140-148.

Necchi O Jr (2004b) Light-related photosynthetic characteristics of lotic macroalgae. Hydrobiologia 525:139-155.

Necchi O Jr, Zucchi MR (2001) Photosynthetic performance of freshwater Rhodophyta in response to temperature, irradiance, $\mathrm{pH}$ and diurnal rhythm. Phycol. Res. 49:305-318.
Platt T, Gallegos CL, Harrison WG (1980) Photoinhibition of photosynthesis in natural assemblages of marine phytoplankton. J. Mar. Res. 38:687-701.

Ramus J (1981) The capture and transduction of light energy. In: Lobban CS, Wynne MJ (eds), The Biology of Seaweeds, pp. 458-492. Blackwell Scientific, Oxford.

Raven JA (1992) How benthic macroalgae cope with flowing freshwater: resource acquisition and retention. J. Phycol. 28:133-146.

Schreiber U, Bilger W, Neubauer C (1994) Chlorophyll fluorescence as a non-intrusive indicator for rapid assessment of in vivo photosynthesis. In: Schulze ED, Caldwell MM (eds), Ecophysiology of Photosynthesis, pp 49-70. Springer-Verlag, Berlin.

Schwarz AM, Hawes I, Howard-Williams C (1996) The role of Photosynthesis/light relationships in determining lower depth limits of Characeae in South Island, New Zealand lakes. Freshwater Biol. 35:69-80.

Steinman AD, Meeker RH, Rodusky AJ, Davis WP, Hwang SJ (1997) Ecological properties of charophytes in a large subtropical lake. J. North Am. Benthol. Soc. 16:781-793.

Thomas MLH (1988) Photosynthesis and respiration of aquatic macro-flora using the light and dark bottle oxygen method and dissolved oxygen analyser. In: Lobban CS, Chapman DJ, Kremer BP (eds), Experimental Phycology: A Laboratory Manual, pp 6477. Cambridge University Press, Cambridge.

Van Den Berg MS, Coops H, Simons J, Keizer A (1998) Competition between Chara aspera and Potamogeton pectinatus as a function of temperature and light. Aquat. Bot. 60:241-250.

Van Kooten O, Snel JJH (1990) The use of chlorophyll fluorescence nomenclature in plant stress physiology. Photosynth. Res. 25:147-150.

Vieira J Jr, Necchi O Jr (2002) Microhabitat and plant structure of Characeae (Chlorophyta) populations in streams from southeastern Brazil. Cryptogamie Algol. 23:51-63.

Vieira J Jr, Necchi O Jr (2003) Photosynthetic characteristics of charophytes from tropical lotic ecosystems. Phycol. Res. 51:51-60.

Vieira J Jr, Necchi O Jr, Branco CCZ, Branco LHZ (2003) Characeae (Chlorophyta) em ecossistemas lóticos do estado de São Paulo, Brasil: gênero Chara e distribuição ecológica. Hoehnea 30:53-70.

Wetzel RG, Likens GE (2000) Limnological Analyses. 3rd ed. Springer-Verlag, New York.

White AJ, Critchley C (1999) Rapid light curves: a new fluorescence method to assess the state of the photosynthetic apparatus. Photosynth. Res. 59:63-72.

Zar JH (1999) Biostatistical Analysis. Prentice Hall, New Jersey. 